\title{
MATERIAL STOCKS AND FLOWS OF EXTENSIVE CATTLE PRODUCTION
}

\author{
SZILÁRD KÁDÁR \\ University of Debrecen, Faculty of Economics and Business \\ Demonstarator of Department of Economics and Business \\ Department of Environmental Economics \\ University level programme: Interational business and economics \\ kadarszilard@gmail.com
}

\begin{abstract}
The current climate change and population boom is the result of the technical developments that aroused by the industrial revolution and the Second Word War. The food shortage arising from that steadily increase poses several problem for agriculture which is exacerbated by the ineffectual operation of the food processing industry. To cover the required amount of food leads higher greenhouse gas emission than $\mathrm{CO}_{2}$ like $\mathrm{CH}_{4}$ and $\mathrm{N}_{2} \mathrm{O}$. Considering this fact I kept it important to find a solution that can be inserted in our countries facility and which is independent from soil usage.

The importance of the cattle breeding sector is that it doesn't require those agricultural lands which could also serve human's need.

I will examine the impact of the extensive cattle with material flow analysis, which is able to show the flows of the specific materials in a given place and in a given time. This calculation is not used count with the pollution and economic factors of the materials.

According to my survey the results show that the examined farms needs 4,$72 ; 4,64 ; 0,24 \mathrm{~kg}$ of material stock per one $\mathrm{kg}$ of meat to maintain the production. This production needs average $10-13 \mathrm{~kg}$ of dry matter input, of which major content is grass. As an unintended emission $\mathrm{CO}_{2}$ emission is also generated: The generated amount of $\mathrm{CO}_{2}$ depends on the Farm structure: in average 11,$32 ; 16,02 ; 16,76 \mathrm{~kg} \mathrm{CO}_{2} /$ meat $\mathrm{kg}$.

To make comparable results it demands weighted averages. That means to make material flow analysis result like feed intake and $\mathrm{CO}_{2}$ emission needs to be weighted with the time which is needed for the production.

It can be claimed that the total $\mathrm{CO}_{2}$ emission of an adult cattle is over $30 \mathrm{~kg}$ per one $\mathrm{kg}$ of meat, and there are no methods to decrease it. But on the other hand the usage of stocks can be reduced by different methods.

The first is the number of the livestock could be increased because it will also increase the efficiency of natural resource usage. On the other hand we can help the farms to co-operate with each other. It allows them to share their stocks. And the last solution is to make multifunctional farms which can produce plants and animals at the same time.

Despite of the high rate of productions' $\mathrm{CO}_{2}$ emission it is still competitive against intensive cattle, owing to the low rate of natural resource requirements
\end{abstract}

Keywords: carbon dioxid, green house gas, material stock, material flow, climate change

\section{INTRODUCTION}

The current climate change and population boom is the result of the technical developments that aroused by the industrial revolution and second word war.

The new technologies made it possible for the population to increase steadily. It led the first doubling of the population by 1959. The population was around 3 billion in that time and in the present over 7 billion (WORLDOMETERS, 2016). The food shortage arising from that steadily increase poses severe problem for agriculture which is exacerbated by the ineffectual operation of the food processing industry (POPP, 2011). One of the reason is wasting. The $30 \%$ of the food goes to waist without processing (TEISLE, 2011).

According to estimates the demand for food will have increased by $60 \%$ percent demand for energy will increased $70 \%$ which is produced by the $30 \%$ population increase (POPP, 2011). 
Meat production requires higher amount of fodder, which can be explained by the living organisms' low metabolic efficiency. Animals can utilize only average $10 \%$ of their feed. Because of the above mentioned losses the rate of crops will increase. On the other hand humans could use that to feed people (THYLL, 1996).

Nowadays $70 \%$ of global soil is used for the production of animal feed. It is used up by intensive farming methods of cattle, swine and poultry (CHEMNITZ ET AL., 2015). Considering the fact that the intensive livestock need less feed they will have fewer greenhouse gas emission than the extensive ones (GARNETT, 2010). Opposite to that the feeding of these animals mean more intensive of soil usage that cause higher erosion of agriculture land (CHEMNITZ ET AL., 2015).

In my opinion the cut of the ever increasing production of crops could be achieved by extensive cattle ranching.

However, in the last 15 years the production was cut back, there are different reasons for the increase the number of cattle.

- $\quad$ According to estimates the food consumption will increase

- In the form of food processing has untapped potential (NÁBRÁNDI ET AL., 2008).

There will be less meat produced in the case of extensive cattle ranching compared to the intensive cattle ranching at the same time there will be less demand for feed. It can successfully use the weaker quality pastures that would be impossible to use for agricultural production. If we examine the green-house gas emission per capita it is much more efficient than intensive farming. At the same time if we examine the production of meat per capita it is much more polluting (GARNETT, 2010).

It provides jobs for more people and helps rural development and population retains rural population (MÁRTON, 2003).

\section{MATERIAL AND METHOD}

My study is based on primary and secondary information. During the collection of secondary information the special searching function of the searching engines like google have been used. All data were collected in microsoft excell.

To determine the animal unite an online calculator was used (I7). So the weight of the calves were taken to $200 \mathrm{~kg}$ the weight of the young cattle were taken to $300 \mathrm{~kg}$ and the weight of the cattle were taken $500 \mathrm{~kg} / \mathrm{animal}$. The age of the calves were taken to 0.5 year old the age of the young cattle were taken to 2 years old and the age of the waste production were taken to10 years old.

The rate of the cattle's meat ration was taken for $65 \%$ of the total weight (KovÁCs, 2002). The amount of emitted $\mathrm{CO}_{2}$ was calculated by the information of (I1) document and for a more precise data in the case of diesel oil I used (I2) online calculator.

The data needed for transporting like fuel consumption was found on websites. It was calculated with a $35 \mathrm{l} / \mathrm{km}$ of fuel consumption (I3) and a maximum 35 number of transportable cattle (I4).

All of the visited Farms sold their production to Turkey. To determine the $2050 \mathrm{~km}$ of estimated distance between Hungary and Turkey the google map was utilized. (I6).

During the determination of the building's weight in every cases with $10 \mathrm{~cm}$ of wall width, 4 meters of inner height was calculated. In the case if the wall lengths were unknown the results were calculated with equal sides. 
The animal feed was grass in every cases. For the results it is important to know that an adult cattle needs $10 \mathrm{~kg}$ of forage in dry matter content in each day (SZATAI, 2007). That will be resulted the $\mathrm{CO}_{2}$ emission.

All the important physical data (for example density) were downloaded from the same website (I5).

My research was conducted with a MFA (Material Flow Assessment).

\subsection{Material Flow Assessment}

MFA based on the balance of the material's flows. It can compare the input and the output of a process. After balancing the input and output side of the process the loss of the material flows will be visible. (BRUNNER AND RECHBERGER, 2004).

It shows the flows of the specific materials in a given place and in a given time. This calculation is not used to count with the pollution and economic factor of the materials (KYTZIA ET AL., 2004, SZABÓ, 2005).

\section{RESULTS}

Table 1. Compositions of the farms

\begin{tabular}{|c|c|c|c|}
\hline Name of the item & I. Farm & II. Farm & III. Farm \\
\hline Cow & 22 & 35 & 965 \\
\hline Bull & 1 & 1 & 54 \\
\hline Young cattle & 13 & 0 & 569 \\
\hline Calf & 22 & 35 & 500 \\
\hline Összesen & 71 & 71 & 2088 \\
\hline
\end{tabular}

Table 2. Structure of material stock

\begin{tabular}{|c|c|c|c|}
\hline Name of the item & I. Farm & II. Farm & III. Farm \\
\hline Building & $37232 \mathrm{~kg}$ & $48066 \mathrm{~kg}$ & $53200 \mathrm{~kg}$ \\
\hline Equipment & $23628 \mathrm{~kg}$ & $27360 \mathrm{~kg}$ & $78560 \mathrm{~kg}$ \\
\hline All & $60860 \mathrm{~kg}$ & $75426 \mathrm{~kg}$ & $131760 \mathrm{~kg}$ \\
\hline
\end{tabular}

Table 3. Structure of material input

\begin{tabular}{|c|c|c|c|}
\hline Name of the item & I. Farm & II. Farm & III. Farm \\
\hline Feed & $156950 \mathrm{~kg}$ & $156950 \mathrm{~kg}$ & $654372 \mathrm{~kg}$ \\
\hline Fuel & $1660 \mathrm{~kg}$ & $\mathbf{2 1 7 0 4 5} \mathbf{~ k g}$ & $152404 \mathrm{~kg}$ \\
\hline & & & \\
\hline Electricity & $594 \mathrm{~kg}$ & $69524 \mathrm{~kg}$ & $11368 \mathrm{~kg}$ \\
\hline
\end{tabular}

These three tables are really important. These tables shows how effect the material stock usage (Table 2) and material flow (Table 3) usage in the size of the farms (Table 1). As we can see the bigger is the farm the less stock is needed. It is because buildings not necessary in the processing (Table 2).

And the more livestock we have the most flow it needs (Table 3). But it is not linear because different age group requires different amount of food (Tables 1 and 3). 
Table 4. Structure of material Output

\begin{tabular}{|c|c|c|c|}
\hline Name of the item & I. Farm & II. Farm & III. Farm \\
\hline Livestock & $\mathbf{1 9 8 0 0} \mathbf{~ k g}$ & $\mathbf{2 5 0 0 0} \mathbf{~ k g}$ & $\mathbf{7 8 0 2 0 0} \mathbf{~ k g}$ \\
\hline Meat & $12870 \mathrm{~kg}$ & $16250 \mathrm{~kg}$ & $507130 \mathrm{~kg}$ \\
\hline Fuel $\mathrm{CO}_{2}$ & $5000 \mathrm{~kg}$ & $6537 \mathrm{~kg}$ & $459050 \mathrm{~kg}$ \\
Electricity $\mathrm{CO}_{2}$ & $2736 \mathrm{~kg}$ & $3201 \mathrm{~kg}$ & $20000 \mathrm{~kg}$ \\
Main product (animal) $\mathrm{CO}_{2}$ & $198397 \mathrm{~kg}$ & $174355 \mathrm{~kg}$ & $8024881 \mathrm{~kg}$ \\
Unintended emission $\mathbf{C O}_{2}$ & $\mathbf{2 0 6 2 2 0} \mathbf{~ k g}$ & $\mathbf{1 8 4 0 9 3} \mathbf{~ k g}$ & $\mathbf{8 5 0 3 9 3 1} \mathbf{~ k g}$ \\
\hline
\end{tabular}

It is clearly visible that the older your livestock is the most weight will it result (Table 4) On the other hand, bigger amount of production will result a higher rate of $\mathrm{CO}_{2}$ emission. The higher rate of the unintended emission came from the main production (Table 4).

Table 5. Unintended output emissions of the farms

\begin{tabular}{|c|c|c|c|}
\hline Name of the item & I. Farm only calves & II. Farm only calves & III. Farm \\
\hline $\begin{array}{l}\mathrm{CO}_{2} \text { emission per one } \mathrm{kg} \text { of } \\
\text { livestock }\end{array}$ & $8.59 \mathrm{~kg} \mathrm{CO}_{2} /$ animal $\mathrm{kg}$ & $8.6 \mathrm{~kg} \mathrm{CO}_{2} /$ animal $\mathrm{kg}$ & $35.22 \mathrm{~kg} \mathrm{CO}_{2} /$ animal kg \\
\hline $\begin{array}{c}\mathrm{CO}_{2} \text { emission per } 1 \mathrm{~kg} \text { of } \\
\text { meat }\end{array}$ & $13.21 \mathrm{~kg} \mathrm{CO} /$ meat kg & $13.23 \mathrm{~kg} \mathrm{CO}_{2} /$ meat $\mathrm{kg}$ & $54.19 \mathrm{~kg} \mathrm{CO} /$ meat $\mathrm{kg}$ \\
\hline $\begin{array}{c}\mathrm{CO}_{2} \text { emission per } 1 \mathrm{~kg} \text { of } \\
\text { meat (with slaughter) }\end{array}$ & $13.249 \mathrm{~kg} \mathrm{CO} 2 /$ meat kg & $13.26 \mathrm{~kg} \mathrm{CO} /$ meat $\mathrm{kg}$ & $54.21 \mathrm{~kg} \mathrm{CO} /$ meat $\mathrm{kg}$ \\
\hline $\begin{array}{l}\mathrm{CO}_{2} \text { emission per } 1 \mathrm{~kg} \text { of } \\
\text { meat (with slaughter and } \\
\text { transporting) }\end{array}$ & $13.63 \mathrm{~kg} \mathrm{CO}_{2} /$ meat $\mathrm{kg}$ & $13.51 \mathrm{~kg} \mathrm{CO} /$ meat $\mathrm{kg}$ & $54.32 \mathrm{~kg} \mathrm{CO} /$ meat $\mathrm{kg}$ \\
\hline $\begin{array}{l}\mathrm{CO}_{2} \text { emission per } 1 \mathrm{~kg} \text { of } \\
\text { meat (with transporting) }\end{array}$ & $13.6 \mathrm{~kg} \mathrm{CO} /$ meat kg & $13.48 \mathrm{~kg} \mathrm{CO}_{2} /$ meat $\mathrm{kg}$ & $54.19 \mathrm{~kg} \mathrm{CO}_{2} /$ meat $\mathrm{kg}$ \\
\hline
\end{tabular}

$\mathrm{CO}_{2}$ emission also depends on the age of the livestock. In this case smaller farms had lower emission per meat because of the higher rate of young calves (Table 5). Bigger companies have more older cattle and waste production.

Table 6. Material Flow Analysis of the Farms

\begin{tabular}{|c|c|c|c|}
\hline Name of the item & I. Farm only calves & II. Farm only calves & III. Farm \\
\hline Stock & $4.72 \mathrm{~kg} / \mathrm{kg}$ & $4.64 \mathrm{~kg} / \mathrm{kg}$ & $0.24 \mathrm{~kg} / \mathrm{kg}$ \\
\hline Input & $12.37 \mathrm{~kg} / \mathrm{meat} \mathrm{kg}$ & $9.83 \mathrm{~kg} / \mathrm{meat} \mathrm{kg}$ & $13.22 \mathrm{~kg} / \mathrm{meat} \mathrm{kg}$ \\
\hline Output $\left(\mathrm{CO}_{2}\right)$ & $16.02 \mathrm{CO}_{2} \mathrm{~kg} /$ meat kg & $11.32 \mathrm{~kg} \mathrm{CO} /$ meat kg & $16.76 \mathrm{~kg} \mathrm{CO} / 2$ meat kg \\
\hline
\end{tabular}

The results show that a bigger company has a better stock efficiency than smaller one. The biggest farm requires 20 times less stock than the smallest one.

Table 7. Overall $\mathrm{CO}_{2}$ emission of the Farms

\begin{tabular}{|c|c|}
\hline Name of the item & Value \\
\hline I. Farm & $31.72 \mathrm{~kg} \mathrm{CO}_{2} /$ meat kg \\
\hline II. Farm & $31.76 \mathrm{~kg} \mathrm{CO}_{2} /$ meat kg \\
\hline III. Farm & $32.61 \mathrm{~kg} \mathrm{CO}_{2} /$ meat kg \\
\hline
\end{tabular}

Every kilogram meat of average 3 years old $500 \mathrm{~kg}$ cattle contains up to $30 \mathrm{~kg}$ of $\mathrm{CO}_{2}$ (Table 7). 


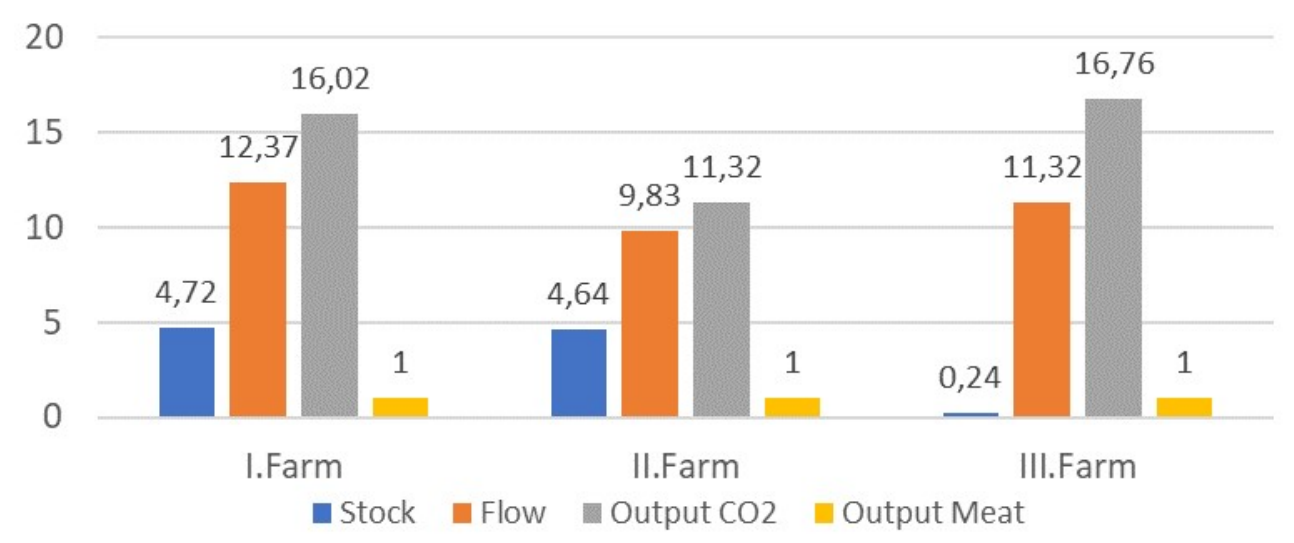

Figure 1: Result of the material flow analysis

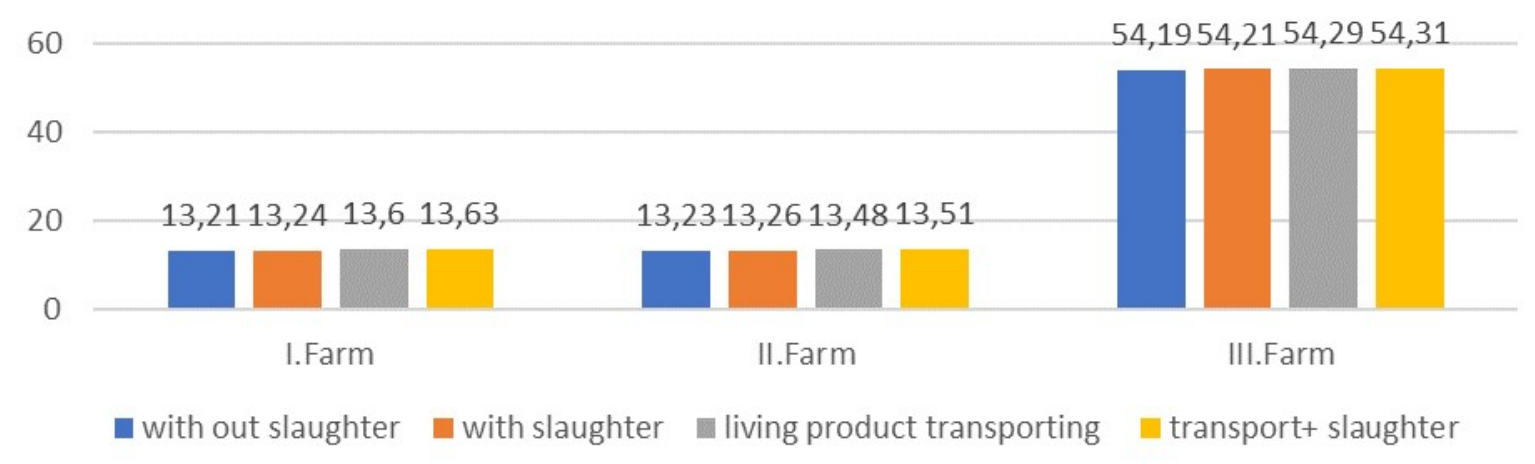

Figure 2: The additional $\mathrm{CO}_{2}$ emission caused by added value

It can be claimed that the added value cause extra $\mathrm{CO}_{2}$ emission but it won't increase the main productions' emission dramatically (Figure 2).

\section{CONCLUSIONS}

It can be claimed based on my results that the main production's unintended $\mathrm{CO}_{2}$ emission during the transporting and the processing is not growing radically. It is because the extra $\mathrm{CO}_{2}$ emission surplus caused by the added value is minimal comparing it to the main production. Nevertheless, it is possible because of the efficient transporting and processing systems.

During the MFA process it was determined that $0.24-4.72 \mathrm{~kg}$ of stock needed to produce 1 $\mathrm{kg}$ of meat. This value is based on the size of the farms. The bigger is a farm the lower material is needed to produce the same level of the wanted production.

If the combination of the stock examined in the case of the small farms, it can be concluded that the weight of the building is bigger than the weight of the tools. But in a bigger company it is opposite down. However, it is because production can be separated from buildings.

In the case of the biggest farm (III. Farm) it is clearly visible that the usage of the materials is more efficient than in the case of a smaller one. Therefore, because the number of livestock is 36 times bigger than in the smallest farm, while the weight of the stocks 
between the two company (I. Farm and III. Farm) is only double. Nevertheless, the reason is because distribution of the tools will be better in the case of the bigger farm.

As the results presented small farms (I. Farm and II. Farm) are using relatively higher rate of tools because they are over-guaranteed.

There are three solutions to decrease the number of used materials. The first is: the number of livestock should be increased to gain the efficiency. On the other hand, farms should cooperate with each other. It allows them to share their stocks. And the third solution is to make multifunctional farms which can produce plants and animals at the same time.

During my study it was also determined that an adult animal releases up to $30 \mathrm{~kg}$ of $\mathrm{CO}_{2}$ emission per each $1 \mathrm{~kg}$ of meat. This result is completely covered by the literature (MACDIARMID ET AL., 2016). This number is higher than in the case of an intensive cattle. In that case the emission is nearly 3 times less: $12 \mathrm{~kg} \mathrm{CO}_{2} /$ meat $\mathrm{kg}$ (MACDIARMID ET AL., 2016). But the intensive cattle can perform this result, only in the case when we use soil to produce feed instead of food. Therefore, it takes soil from the agriculture.

\section{ACKNOWLEDGEMENTS}

This work was supported by the National Research, Development and Innovation Office NKFIH, K-115851

\section{REFERENCES}

(I1): (dr. Víg András) $\mathrm{CO}_{2}$ számítás http://energia.salgopc.hu/?wpfb_dl=119 (downloaded: $01.10 .2016)$

(I2): $\left(\mathrm{CO}_{2}\right.$ kalkulátor) http://www.sunearthtools.com/ (downloaded: 05.10.2016)

(I3): fogyasztásahttp://totalcar.hu/tesztek/haszon/2010/05/27/ket_napig_a_csucson/ (downloaded: 02.10.2016)

(I4): (szarvasmarha szállítás) http://zaol.hu/gazdasag/elo-allat-a-kamionban-1486247

(I5): (I2): anyag sürüségek http://mek.niif.hu/00000/00056/html/083.htm (downloaded: $02.10 .2016)$

(I6):https://www.google.hu/maps/dir/T\%C3\%B6r\%C3\%B6korsz\%C3\%A1g/Magyarorsz\% C3\%A1g/@42.9449665,22.8636833,6z/data=!3m1!4b1!4m13!4m12!1m5!1m1!1s0x14b01 55c964f2671:0x40d9dbd42a625f2a!2m2!1d35.243322!2d38.963745!1m5!1m1!1s0x47418 37bdf37e4c3:0xc4290c1e1010!2m2!1d19.503304!2d47.162494 (downloaded: 02.10.2016) (I7)

http://www.gazdavilag.hu/index.php?option=com_content\&view=article\&id=67\&Itemid= 12 (downloaded: 02.10.2016)

BrunNer, P., Rechberger, H. (2004): Practical handbook of material flow analysis. Lewis Publisher ISBN 00-203-50720-7

ChEmNitz, C., Becheva, S. (2015): Húsatlasz 1091 Budapest, ISBN 978-963-9802-07-0

ORIGINAL: ISBN 978-80-906270-0-0

KovÁCs, T. (2002): Marhahús termelés és feldolgozás aktuális gazdasági kérdései. Mosonmagyaróvár 2002

KYTZIA, S., FAIST, M., BACCINI, P. (2004): Economically extended-MFA: a material flow approach for a better understanding of food production chain. Journal of Cleaner Production 12: 877-889 p.

MÁRTON, I. (2003): A húsmarha tenyésztésének és tartásának gyakorlata. Szaktudás Kiadó, Budapest, 122 p., ISBN 963-9553-05-0 
POPP, J. (2011): KAP-reform http://slideplayer.hu/slide/2107471/ (downloaded: 2016.01.15)

Pupos, T., TAKÁcsné, K., NÁBRÁdI, A. (2008): Üzemtan II. Szaktudás Kiadó Ház Rt., Budapest, 376 p., ISBN: 978-963-973-6924

SzABÓ, F. (2005): Húsmarhatenyésztés. Mezőgazda Kiadó, Budapest, 375 p. ISBN: 978963-286-482-2

SzATAI, Zs. (2007): Műtrágyázatlan és mütrágyázott gyep kémiai összetétele, hozama és húsló eltartó képessége. Kaposvár

TARA, G. (2010): intensive versus extensive livestock systems and greenhouse gas emissions., FCRN briefing paper

TEISLE, M.F. (2011): Environmental concerns in food consumption.

THYLl, Sz. (1996): Környezetgazdálkodás a mezőgazdaságban. Mezőgazda Kiadó, Budapest, 417 p. ISBN: 963-9121-97-5

WORLDOMETERS (2016): http://www.worldometers.info/hu/, (downloaded: 25.01.2016) 